\title{
Re-prioritizing Teachers' Social Emotional Learning in Rural Schools Beyond Covid-19
}

\author{
June Monica Palmer \\ Central University of Technology, Free State \\ Edwin Darrell de Klerk ${ }^{1}$ \\ Sol Plaatje University, Northern Cape \\ Motalenyane Alfred Modise \\ Central University of Technology, Free State
}

\begin{abstract}
The inception of lockdowns by governments across the globe to control the spread of the COVID-19 pandemic has exposed many disparities in rural societies, particularly on the African continent. The social, cultural, and psychological processes have elicited variations in teachers' responses to the devastating pandemic, illuminating African cultural realities in the quest for creating quality delivery of teaching and learning in schools. When teachers regard themselves as transformative change agents and not merely as oppressed people, this confirms their social identities and cultures and afford them opportunities to engage in critical reflection on the messages they convey in their classrooms. This case study employs semiotic analysis to explore some socio-cultural messages and emotional behaviours teachers exchange unwittingly in schools. Interviews were conducted via e-mail, as face-to-face contact with the respondents was not possible. The findings indicate that teachers conceive of themselves as disempowered "lay people" who are ill-equipped to respond adequately to situations such as the coronavirus pandemic, but are, nonetheless, "accountable" to the communities they serve. As its contribution, this paper presents teachers with the Social-Emotional coping skills of individual awareness, social awareness, and self-discovery, to help them thrive during periods of uncertainty. A semiotic reflection on the learning environment may empower teachers with inclusive and transformative strategies for ensuring their own and learners' emotional well-being in a non-threatening learning environment beyond COVID 19.
\end{abstract}

Keywords: African cultural realities, COVID-19, semiotic interpretive approach, social emotional learning.

The outbreak and spread of COVID-19 were first made known in Wuhan, China, in 2019 and has had devastating consequences followed ever since. The consequences of the virus resulted in the World Health Organisation (WHO) declaring Covid-19 a worldwide epidemic on March 11, 2020, based on the way it was spreading and destroying human lives (Mahaye, 2020). The first confirmed case of Covid-19 in South Africa was reported on March 5, 2020. On March 15, 2020, a nationwide state of disaster was declared by the South African

\footnotetext{
${ }^{1}$ Correspondent Author E-Mail: edwin.deklerk@spu.ac.za
} 
government (Republic of South Africa, 2020) in an effort to contain its spread and to ensure a gradual infection rate. Subsequently, a national lockdown was declared, which necessitated restrictions on businesses and signalled the closure of learning institutions (Republic of South Africa, 2020).

Mahaye (2020) asserted that when an education system loses extended periods of learning and teaching due to events such as those described above, disruptions of the curriculum are an inevitable consequence, thereby impacting on the well-being of teachers. The imperative on teachers, as with many stakeholders in schools, was to work from home, while fearing to interact with other individuals, as well as to adapt their teaching and learning approaches, causing much stress and anxiety (Mahaye, 2020). It is noteworthy that teachers' emotional challenges have been documented long before Covid-19.

The fight against Covid-19 and tight global isolation measures echo the profound psychological consequences of stress-related circumstances for many teachers. The Belgium Lifelong Learning Platform (2020) reported that, during the pandemic, many teachers experienced anxiety, depression, fear for self and others, inertia, and stress. Such emotional experiences were exacerbated by having to apply new evaluation methods, a lack of digital competency, and a sense of loss of their (and learners') cultural realities in order to respond adequately to external threats to their well-being. Culture may be regarded as critical to knowledge production, and, in the teaching and learning context, they are interrelated. If they are separated, learning becomes mechanical and irrelevant, hindering learners' ability to transfer the knowledge they have acquired (Azevedo et al., 2020).

Undoubtedly, COVID-19 has impacted on the expression of African cultural values and practices. An African-centred paradigm insists on an African space where Africans can have the latitude to express and interpret their rich experiences and culture, primarily through the education process, for knowledge generation (Bent-Goodley et al., 2017). In a recent study, Fataar (2020) revealed that the "new normal" in educational institutions, such as schools, during the Covid-19 pandemic created numerous challenges for teachers, as they expressed their anxiety and eagerness to figure out how best to engage in curriculum delivery. As a curricular imperative, online and multimodal teaching approaches were applied, while teachers reported feelings of fatigue, and fear of infection, and were concerned about whether the work learners did completed at home was adequately mastered (Fataar, 2020). A survey of teachers in the United States revealed that social-emotional support ranked high among their needs as they struggled with psychological well-being challenges during the Covid-19 pandemic (Green, 2020). The findings reiterated revealed that, while US teachers mostly felt anxious, fearful, worried, and overwhelmed, they were more worried about working from home full time while figuring out how to transfer their teaching practice to online platforms (Green, 2020).

Ongoing research is necessary to explore teachers' narratives regarding their experiences during the Covid-19 pandemic (Bongani, 2020), because the psycho-social care of teachers has not been given adequate attention. A recent study signposted that teachers' socialemotional abilities do not appear to enjoy prominence in teacher training (Schonert-Reichl, 2017). Additionally, the cultural realities of teachers have been neglected at the expense of delivering a curriculum during a global pandemic. Teachers need to feel that they are being listened to, so that "they may be able to articulate their needs for support" (McDonald, 2020 as cited in Bongani, 2020, p. 1). The research gap addressed in this study was the need to investigate some of the socio-cultural messages and emotional behaviours that teachers in selected Northern Cape schools exchanged unwittingly during Covid-19. Pertinently, the research question this paper explores is: How may Social and Emotional Learning (SEL) strategies contribute to teacher's well-being beyond Covid-19? 


\section{The Teaching and Learning Quality Imperative}

Given an array of perspectives on and approaches to the notion of quality, the question of what quality of teaching and learning is, remains crucial. Kim et al. (2019) contended that, to facilitate an understanding of the delivery of quality teaching and learning, it is incumbent upon teachers to reflect on their practices. In this regard, four descriptions of quality relating to teaching and learning stand central (Harvey \& Green, 1993 as cited in Henard \& LeprinceRinquet, 2008). Firstly, quality can be defined as "excellence" - this impression of quality is the dominant one in many educational organizations. Secondly, quality can be defined in terms of accountability in that an institution that regards quality as fundamental is one that gratifies the demands of public accountability. Thirdly, quality may be regarded as "fitness for purpose" in that educational institutions emphasize the significance of efficient learning. Lastly, quality can be regarded as "transforming." According to this definition, the aim would be to transform learners' opinions and how they apply knowledge to actual challenges in the world. Drawing on the latter descriptions, this paper argues that excellence, accountability, purpose, and transformation should contribute to enhance the breadth of abilities necessary for quality learning and teaching; thereby contributing towards inspiring those critical skills necessary for promoting quality education in contemporary times (Darling-Hammond et al., 2020).

The reality of Covid-19 requires a rethinking of what quality of teaching and learning may suggest (Dhawan, 2020). Although online teaching and learning seem to be an ideal way of ensuring that quality in education is not jeopardized, the shift from face-to-face engagement to online learning has proved to be distressing in certain learning contexts. In the COVID-19 pandemic state, teachers have, almost instantaneously, been requested to be both creators and instructors, and to navigate their learning spaces using tools that few have confidently mastered (Rapanta et al., 2020). Liguori and Winkler (2020) reflected on teachers having to adopt innovative ways of teaching by combining e-learning with customary approaches in order to ensure competence, efficiency, and reasonable control, and, in so doing, sustain quality in teaching and learning. Saxena (2020) reported that in India, teaching and learning programs have progressed efficiently for several years now, where learners are trained in online etiquette, and given proper instructions. This implies that teachers ensure that they use precise language, repeat important information frequently, provide a clear explanation of tasks, and ensure that learners understand what is expected from them (Saxena, 2020) - all efforts to maintain quality in education. Burns and Lawrie (2015) recommended that, to improve the quality of learning and teaching, an emphasis should be placed on more organized, simplified opportunities for teachers to obtain information, an improved consideration of the circumstances in which they perform their work, and the use of upgraded information to ascertain what can be done.

Additionally, to maintain the quality of learning in contemporary times, teachers should consider instructional support strategies such as scaffolding, providing high-quality feedback, considering learners' ideas and interests, as well as providing emotional support to learners (Wolf et al., 2018) as necessary tools. In designing new learning approaches, teachers simultaneously act as tutors and performers. For example, teachers need to both design tasks, and manage the learning environment and resources that help their students learners learn. While it is required that they teach the intended curriculum, it is also expected that they shift agilely between roles as planners, teachers, and guardians of learners (Rapanta et al., 2020).

Significantly, most countries experience compromised principles for quality, regulation, and the development of digital resources, and ensure that curriculum content is delivered through digital technology devices (Halpern, 2020). Dhawan (2020) posited that such challenges should be addressed so that everybody can appreciate the advantages brought forward by online learning to ensure that quality education is offered in schools. The emphasis should be, therefore, not solely on the advantages of virtual education during the Covid-19 
pandemic, but also on the improvement of the quality of computer-generated learning, should be regarded as significant, particularly during periods of intensified anxiety and stress (Affouneh et al., 2020; Namli, 2021).

\section{Considering Teachers Cultural Realities and The Psychological Effects of COVID 19}

Many emotional difficulties imply consequences for teachers in terms of their psychological well-being Such consequences includeing frustration, anxiety, stress, uncertainty, and depression, which appear to have increased during the COVID-19 epidemic (Duan \& Zhu, 2020). Common psychosomatic responses, related to the mass isolation that was enacted worldwide in an attempt to lessen the COVID-19 spread, include comprise widespread anxiety and persistent fear, which are stereotypically connected with disease epidemics, and worsened by the proliferation of novel cases together with insufficient, fear-provoking statistics, anxiety or shared panic to general feelings of distraction and hopelessness (Kelley, 2020; Thakur \& Jain, 2019).

Studies conducted on the psychological well-being of teachers in India and Korea found that teachers generally experienced psychological challenges in terms of relating to fears of how to keep their students learners on track amidst distractions from social networking sites, (Namrata, 2020) amidst and the adoption of virtual classrooms (Madeline, 2020), and stress to convert teaching materials into online notes within a short time (Veena et al., 2020). In the South African context, teachers have mainly experienced psychological challenges such as deteriorating mental health and high stress levels (Macupe, 2020), long working hours, and little consideration for their ideas on dealing with teaching and learning (Ramrathan, 2020). Furthermore, while some South African teachers were stressed because Covid-19 was responsible for an initial halt in the curriculum (Van der Berg \& Spaull, 2020), others needed massive emotional and psychological support (Jansen, 2020). Considering teachers' cultural realities and providing psycho-social and professional support will boost their performance (Parker et al., 2020).

Conceiving of a definition of culture is an immense task as it is understood differently by many individuals. However, for behavioural experts, culture is a collection of human behaviour patterns. Idang (2015) indicated that culture includes signifies information, confidence, skill, regulation, ethics, practice, and any additional competencies and lifestyles attained by individuals. Cultural reclamation to decolonize African education systems by providing educational courses that are practical and socially approachable to African prerequisites are imperative. Postcolonial African education continuously reconstructs realities that represent a crisis relevant to individuals' character and identity perception. This creates a gap between what schools teach and what most learners experience in their homes and communities (Hapanyengwi-Chemhuru \& Makuvaza, 2017). An African perspective on teachers' cultural realities implies that they (teachers) can apply the survival power of partnership and cooperation and reconstruct self-identities for learners by portraying messages and behaviours associated with empathy, reciprocity, and hospitality, among others (Jandrić et al., 2020). More than four decades ago, Banks Henries (1977, p. 128) proclaimed that an "African cultural reality cannot be isolated from the demands of modern living in a technological age." It is an essential feature of cognizance as teachers plan and enact their roles in society. While it is crucial for positive regard, devotion, and international and national harmony, it should similarly be considered as an advantage in intercontinental relationships and fundamental for the permanency of an African culture (Banks Henries, 1977). Teachers should, therefore, be mindful that they are "inhabited by [the world], and [are] able to co-construct the social and cultural world" (Holland \& Lachicotte, 2007, pp. 134-135 as cited in Oswald \& Perold, 2015). 
Accordingly, during the reign of this pandemic, teachers must adapt and self-regulate mentally, physically, and emotionally (Jandrić et al., 2020). When teachers become cognizant of the realities in which they find themselves, they should understand that "one's understanding of the multi-layered, independent and nonsynchronous interaction of social status, language, race, ethnicity, values and behaviours that permeate and influence nearly all aspects of our lives" (Taylor, 1999, p. 232 as cited in Berry et al., 2013). All these issues affect teachers' views of the world and inform their experiences, socio-cultural messages, and emotional behaviours.

\section{Teachers' Social Emotional Learning (SEL)}

Teacher well-being, often considered one of the areas most neglected, is influenced by aspects such as fulfilment and contentment, and includes promising emotional functioning (Glazzard \& Rose, 2019). SEL may strengthen teachers' emotional functioning, implying that they can easily engage with others and know how to conduct themselves positively during reallife challenges (Caldarella et al., 2019). In the context of this study, the definition of SEL by the Collaborative for Academic, Social, and Emotional Learning (CASEL) is most appropriate:

\section{The process through which children and adults acquire and effectively apply the knowledge, attitudes, and skills necessary to understand and manage emotions, set, and achieve positive goals, feel and show empathy for others, establish and maintain positive relationships, and make decisions. (CASEL, 2019, p. 1)}

An application of SEL holds positive results for individuals in that they are provided with approaches to deal with expressing and adopting emotional and social experiences, which subsequently help them to reinforce their capacity to collaborate successfully, exercise selfcontrol, and to plan effectively (Blewitt et al., 2020). Significantly, collaboration requires sufficient time, emotional and social abilities, openness to innovative thoughts, and courage (Weisberg, 2020).

To fully understand the benefits of SEL for teachers, especially during the Covid-19 pandemic, this paper argues that it is crucial to consider a system of SEL that changes people in ways that provide for maximum development, irrespective of their statuses or contexts (Jagers et al., 2018). This implies that teachers should be able to portray transformative social and emotional capabilities such as social awareness, responsible decision-making, selfmanagement, relationship skills, and self-awareness (Ferreira et al., 2020). Significantly, transformative social-emotional learning becomes useful when teachers' skills and abilities are improved and refined through proficiencies which may contribute to the establishment of effective teaching and learning settings that will affording opportunities for collective analysis, exploration and problem-solving in everyday circumstances (Darling-Hammond et al., 2018).

\section{The Researchers' Interest in This Study}

The researchers of this study are academics at two different higher education institutions in South Africa. Our research interests encompass topics such as transformative learning, social emotional learning, empowerment of pre-service teachers, advancing learning in rural schools, teacher and learner autonomy as well as emotional intelligence. Whilst conducting research on the impact of Covid-19 on education since April 2020, we engaged in conversation with teachers to understand their experiences with teaching and learning amidst this pandemic. Notably, Covid-19 has uncovered many insufficiencies and inequalities in education systems around the world - from access to the internet and computers required for virtual instruction, 
as well as the influence on supportive settings needed to focus on teaching and learning. Consequently, the afore-mentioned issues motivated us to conduct research on teachers' socialemotional learning skills in rural schools.

\section{Theoretical Framework} Notably,

Social emotional learning theory (SEL) will be applied as theoretical lens in this study.

Social and emotional learning (SEL) involves the processes through which children and adults acquire and effectively apply the knowledge, attitudes and skills necessary to understand and manage emotions, set and achieve positive goals, feel and show empathy for others, establish and maintain positive relationships, and make responsible decisions. (Collaborative for Academic, Social, and Emotional Learning [CASEL], 2013, p. 6)

Derived from the afore-mentioned definition, SEL may be interpreted as the ability to identify and manage feelings, solve problems efficiently and establishing constructive interactions with individuals. SEL may assist in developing skills like (CASEL, 2013): (i) selfawareness - comprises the acknowledgement and identification of personal emotions, sense of self-confidence and self-efficacy; (ii) social awareness - having compassion and reverence for other individuals; (iii) responsible decision making - includes reflection and evaluation as well as individual and moral accountability; (iv) self-management - includes anxiety management, diligence, motivation and goal setting; as well as (v) relationship abilities - comprise communication and collaboration.

Covid-19 has, among other things, not been kind on the mental and physical health of teachers. The isolated lifestyle has changed the definition of socialisation and has led teachers to experience a variety of feelings (Srivastava, 2020). SEL is thus relevant to this study because it may offer teachers coping skills of personal awareness, social awareness, positive approaches about others and the self, encouraging social behaviour and tools to reduce emotional distress during times of a pandemic.

\section{Methodology}

This study employed a qualitative methodology to define and examine the world as it is interpreted, understood and experienced by the participants in their daily lives (Aspers \& Corte, 2019; Cropley, 2019).

Consequently, this qualitative research will use a case study approach because it is considered to convey information from the perspective of the respondents. The case study method "explores a real - life, contemporary bounded system (a case) or multiple bounded systems (cases) over time, through detailed, in depth data collection involving multiple sources of information... and reports a case description and case themes" (Creswell, 2013, p. 97). Considering Creswell (2013), we employ a case study design because of its distinctive characteristics including being (Merriam, 1998): particularistic (it emphases on a specific situation, occasion, platform, or phenomenon - in this instance teachers' social emotional learning SEL in rural schools beyond Covid-19); evocative (it produces a rich portrayal of the phenomenon) and experiential (it irradiates the reader's understanding of phenomenon) (Merriam, 1998, Yin, 2011, 2017). Additionally, a case study does not only hinge on pragmatic material collection and analysis, but also on its reporting which comprises facets such as 
participant description, case description, relationship description, interpretation and analysis (Denzin \& Lincoln, 1998).

Key to this research was teachers' voices in investigating an existing phenomenon within its actual setting (Ebneyamini \& Moghadam, 2018). Although ten teachers from different schools were requested identified to participate in this study, only five responded. The respondents participants are hail from schools which are situated in rural communities with characterised by underprivileged socio-economic circumstances which are characterized by among others including poor accommodation, poverty and an absence of economic power. The afore-mentioned encounters resulted into rural schools with pitiable structures and insufficient resources.

Teachers were given an opportunity through in-depth e-mail interviews to express their views regarding their social-emotional well-being during the COVID-19 pandemic. Due to social distancing regulations, and for safety reasons, interview questions were e-mailed to participants, who provided rich data in a more structured way, because the data did not involve as much repetition as is the potential case with face-to-face-interviews (Ratislavová \& Ratislav, 2014). Purposive sampling was used to select the participants, because of their potential to provide the requisite data for the study, and because their involvement would mean that they would have had the richest possible experiences (Ames et al., 2019) regarding teaching and learning during Covid-19. The interviews took place between June and July 2020.

This study explores some socio-cultural messages and emotional behaviours teachers exchanged unwittingly in schools during Covid-19, by analysing data through a semiotic interpretive approach. Semiotics can may assist academic scholars in making meaning of the world through collaborations with participants (Yamagata-Lynch et al., 2016). This paper adopts Peirce's (1992) description of semiotics as a way of looking at our existing knowledge base, i.e. how we know what we know, and at ways in which we communicate about the things we know. The basis for Peirce's work in semiotics indicates that signs, objects, and interpretants are in a relationship with one another. The object represents whatever can be represented, a sign is an influence that an object has on individuals, and the interpretant represents emotions, actions, or opinions that are induced as a consequence of individuals' interaction with both object and sign (Houser, 1987 as cited in Yamagata-Lynch et al., 2016). In our analysis we identified Covid-19 as the object influencing the socio-cultural emotions and behaviours of teachers. Subsequently, we will then act as interpretants deriving meanings and understandings from the identified signs, notably mapping the changes teachers experience in their socialemotional learning.

The five in-depth interviews were translated, where necessary, and analysed by means of coding (Creswell, 2007). Coding comprises working through the data and recognizing and allocating codes to key concepts (Leedy \& Ormrod, 2005). Once the data were coded, they were categorized and analysed to identify themes (McMillan \& Schumacher, 2014). Themes were recognized by the main issues identified from the grouped codes. To ensure trustworthiness, responses were abstracted by each researcher independently. Afterwards, notes were compared, and agreement on the final code and theme classification was reached. Additionally, a member check of written findings was done (Korstjensa \& Moserb, 2018). Returning the written interpretations and conclusions to the participants via e-mail ensured that the data were strengthened, especially because researchers and participants could view the data in different ways.

\section{Findings}

This study aimed to explore the social-emotional well-being of rural school teachers during a time of crisis. The findings revealed that teachers generally experience heightened 
emotions due to the unprecedented challenges brought about by the COVID-19 pandemic. They labelled typical emotional states such as feelings of isolation, fear, anxiety and wandering out of control as those they experience daily. Teachers were vocal about the unexpected demands (personal and job-related) that have been placed on them and they find it increasingly difficult to cope. The data further revealed that, teachers were often the only resource available to their learners in caring for and supporting their learning progress, impacting on their social and emotional functioning.

In presenting the findings, codes T01 to T05 were used to identify the participants. The themes that emerged from the study include teachers' emotional well-being, psycho-social support during COVID-19, and teachers' cultural realities. To ensure reliability and validity of the findings, we, like Merriam (2002) ask the question: How consistent are our findings with reality? Addressing these issues, we argue that the findings are consistent with current research regarding the impact of Covid-19 on educational issues such as teachers' social emotional learning. For example, Eddy et al. (2020) found that, particularly amid the worldwide disturbance of COVID-19, SEL will be front and centre for many teachers and, therefore, the social and emotional desires of teachers, among others, will be crucial as re-entry into education transpires.

\section{Teachers' Emotional Well-being}

In answer to the question of their most frequently experienced emotions during the pandemic, teachers were unanimous in describing their lived fears, anxieties, and even sadness about the raging Coronavirus impacting their daily activities. Some recorded feelings of intense fear and a loss of control over the situation as they had to comply with lockdown regulations and teach online. For others, the situation presented an opportunity to make calculated decisions for the safety of themselves and others. Koutsimani et al. (2019) contended that the problem of teacher stress, especially during periods of uncertainty, is universal. It manifests across all segments of education and countries (Koutsimani et al., 2019) and results in exhaustion and lower job fulfilment, which leads to an increased risk of developing adverse psychological effects. Participants reacted as follows:

Having co-morbidities, myself, I was at home for most of the time, and the stress, heartache, and sense of loss was very intense. At times I felt suicidal and had to be hospitalized once. This increased my fear of dying of the Coronavirus in hospital [T01].
I feel like this is not me anymore...I'm constantly stressed and on edge because there's just too many demands on us. I don't know myself anymore [T05].

It is challenging to navigate through this pandemic, but schools were very organized and systematic concerning facilitating the welcoming back of learners. One participant noted the following:

A COVID-19 committee has been established that keeps tabs on reports and intel pertaining to the pandemic and whether transparent measures are put in place. As learners were gradually ushered back to school, we had orientation as to how the school will function under a strict compulsory protocol of sanitizing, temperature screening, questionnaires, and demarcated areas for movement. This was our new normal [T03]. 
To deal with the challenges of reopening schools, it is crucial to be directed by factors such as ensuring the safety for all, planning for an all-encompassing re-opening, listening to the opinions of all concerned, and coordinating with significant stakeholders, in order to suppress transmission of the virus (UNESCO, 2020). T04 lamented in the following way:

\begin{abstract}
We were never ready for this. Coronavirus caught us off-guard and now we are expected to comply to all the changes. You know, moving to online learning just like that here in our school is stressful, I have to take medication to cope.
\end{abstract}

It feels like people are pulling me in a lot of different directions, my learners require my support but I feel so helpless, so sad for them too but what's so strange is that the department expects me to function as normal. This is an abnormal situation [T02].

Acceptance and surrendering to the situation, I have no choice here. With the passage of time, I realized that no one can be blamed for the situation we are in and how helpless we feel at times [T03].

CASEL (2013) regarded SEL as the ability of adults and children to learn to manage and understand their emotions, demonstrate compassion to others, set objectives, make answerable choices and foster positive relationships. The experiences of the teachers reflect the opposite, that they are clearly not equipped to handle their emotions in a changing teaching and learning situation.

Darling-Hammond et al. (2020) believed that when children observe those who are close to them displaying resilience and perseverance when challenges arise, they themselves become more self-reliant. It seems that the social context may be vital for the improvement of capabilities that require willpower, specifically when it offers teachers as role models, who may support learners in challenging learning contexts, and ultimately achieve realistic, long-term goals (Kundu, 2017).

The data generated, pointed out that, although teachers felt safe and secure at home at the beginning of the lockdown, the uncertainty about the pandemic's duration and the completion of the curriculum evoked panic and overwhelmed them. T02 said:

Despondency, stress, and loss of control consume me daily. I feel emotionally disconnected from my learners, as I am expected to fulfil many roles and execute so many tasks. What about those learners who need extra attention? Will they get it at home? My colleagues and family and the community, in general, were so complacent about the danger of infection, and it just debilitates me [T02].

Smith and Joffe (2013) highlighted the role of the emotional context in modern societies where frequent emotional displays are evident when someone responds to danger, with fear, coupled with apprehension, featuring very prominently. The result is emotional fatigue (Sherlaw \& Raude, 2013). T05 mentioned:

I felt very tired and anxious about the effects of the virus on myself, family members, learners, colleagues, and parents. So many of my learners' parents were uneasy regarding the rest of the academic year. 
They were constantly checking if teachers were working with learners, and they were worried about their children's safety.

Interestingly, in describing her emotions during the lockdown, one of the five participants was content and indicated:

I was relaxed, grateful, and happy, but at the same time, I felt really helpless. I had time to spend on my hobbies, time I never had for myself before. As teachers, we struggled with curriculum delivery, though, as many of our learners cannot read or write, and we did not have an online tutor service ready when the lockdown was instituted. This resulted in me not having contact with my learners. We were totally disconnected [T04].

In addition to the comments above, other participants confirmed that they did not have any communication with their learners, as online teaching and learning was non-existent in some of their schools. The issue of inclusivity was highlighted:

No, teachers and learners were not taken into consideration. At our school, we have learners who have hearing aids and lip-read. Although see-through screens were provided, it steams up, and the learner is not able to follow. Our school also has no ventilation, and most of our cleaning staff members have a comorbidity, leaving it to the teachers to clean their own classrooms [T04].

We are lucky at our school because we use a program called Future Fun Caps even before the lockdown period. The online switch has its own challenges: not all learners have the Internet at home and constantly complain about connectivity. This caused double lesson planning - planning for online teaching and ensuring that printed copies war available for those who struggle with access to digital technology [T05].

With the advent of COVID-19, the sources of teacher stress grew exponentially. Having to perform a balancing act between their individual and professional lives presented a real test for several teachers. Concomitantly, online curriculum distribution, having to work from home, and being assigned inescapable tasks that need to be completed online, inevitably created a disconnect between physical and psychological limits which may exist between the school and the home (MacIntyre et al., 2020).

\section{Psycho-social Support During COVID-19}

The COVID-19 pandemic disrupted the lives of teachers and learners in different ways. Loss of control and authority were aspects that all the teachers spoke fervently about. They declared it as debilitating, and they felt exposed to infection, and powerless to control the actions and mind-sets of those around them. To the question on the level of support they were given at their schools, two participants indicated:

Apart from the circulars and e-mails sent to teachers to inform them of "new developments," we did not receive any psycho-social support [T01]. 
Another said NONE, every man for himself. We are just expected to adapt and cope with the situation. This is unfair [T02].

Other participants remarked:

The support provided by the SMT was good; they were doing their best to listen to our concerns, pacifying, and addressing any grievances and insecurities teachers might have. At the start of each morning, a staff meeting was held, and the floor was open to discussions and brainstorming of how the school can be administered safely and efficiently, according to regulations. I really felt part of the team [T03].

We do not receive any psycho-social support. We were "trained" the first few days, and most of it did not come to fruition since we were understaffed, with many teachers reported to be having co-morbidities [T04].

According to the participants, their commitment to quality teaching and learning goes by unrecognized. They wish their learners to know that that they care and have their best interests at heart and that they are psychologically stable, and calm, and would protect them at any cost. Furthermore, psycho-social support has a significant effect on teachers' job satisfaction (Čecho et al., 2019).

\section{Teachers' Cultural Realities}

Culture is construed as a distinct habit of the mind, the advancement of the entire society, the arts, and the entire way of life of a group of individuals. As illustrated in Katbi and Abdeen (2016), culture was is understood in two ways, i.e. a foundation of self, and a source of theatre where different ideological and political outcomes engage one another. The teachers described their cultural realities in terms of their experience of equity in the school and community, respect for different races, cultures, religions, and languages, sense of safety and security, as well as inclusivity and transformation in terms of quality education provided to all learners. For instance, teachers said that the pandemic had far-reaching implications that permeated almost all aspects of a person's life. In particular, cultural practices and behaviours that built cohesive teams now made way for low self-esteem, lack of confidence, and reverence for the cultures of others. To a question on the impact of the pandemic on cultural practices of teachers and learners, participants mentioned the following:

Since the pandemic, everyone is very cautious and hesitant to interact with each other adhering to directives and precautions of the national state of disaster. Restrictions on our religious practices have hit the hardest, and, in some instances, you can see the moral decay happening in society. Children are not respecting their elders anymore [T03].

For me, communication deeply suffered. In our culture, we thrive on communicating and interacting, strengthening the bonds, and practicing Ubuntu. It could simply not happen because we were far removed from our learners [T01]. 


\begin{abstract}
This is survival mode. Our Ubuntu caring is so much neglected I feel, this COVID-19 has almost forced us into a situation where it it's really become about me and my family and our safety, but there is so much need in our community, so much need. It is sad [T01].
\end{abstract}

Ubuntu provides the framework within which actions are evaluated and is premised on the idea of interconnectedness and the development of a healthy society (Ewuoso \& Hall, 2019). Le Grange (2020) reiterated that the Covid-19 pandemic created specific ethical predicaments for all stakeholders of education. In South Africa, schools are spaces where learners from vulnerable communities require more support than merely a knowledge exchange from their teachers, schools are also safe spaces for them: As part of the National School Nutrition Programme (NSNP), more than 9 nine million children receive 2 two meals per day at school. However, the NSNP was temporarily suspended during the lockdown period and level 4 four of the government's risk-adjusted approach. This left these children at risk of being malnourished during periods of school closures. Supporting the teachers, who, due to the pandemic, considered themselves to be in a compromised position both to respond adequately to learners' diversity, and quality and equitable provision of education, should be regarded as important.

\title{
Discussion and Implications
}

The findings helped draw inferences about how teachers navigate signs (COVID-19 and teachers' feelings, fears, and anxieties) under challenging contextual circumstances. Teachers expressed themselves eloquently regarding a number of issues, i.e. their experiences of feeling threatened by the pandemic itself, and the emotional and psychological effects that the lockdown had on their functioning.

Anxieties and frequent uncertainties about the future emerged as mutual common stressors. Teachers indicated that they felt powerless over the spread and impact of the Coronavirus and characterized it not only as something to be feared but also as a highly contagious enemy. Current notions on COVID-19 indicate that especially teachers and learners perceive the pandemic as an enemy. However, remarkably, to them the problem was never the disease itself, but rather other entities such as the government or the media, or their fellow citizens whom they perceived as conducting themselves in an uncivilized manner by disregarding the destruction brought by the pandemic (Idoiaga et al., 2020). Teachers generally agreed that there are some heroes, such as the healthcare professionals and the victims, such as the vulnerable and the elderly (Idoiaga et al., 2020). Teachers expressed their anxiety, sadness, fear, and disillusionment with the pandemic and the situations they faced at their schools at the time. This finding highlights the much-needed emotional lift that psycho-social support may provide to teachers; it may just affect their mood, functioning, and overall attitude to work (Stephen et al., 2019).

In their responses, some teachers revealed emotions of contentment and happiness. Scholars on positive psychology agree that (MacIntyre et al., 2019) it is vital to embrace measures of both types of outcomes (positive and negative), as "well-being" is not merely the lack of undesirable function, but rather something more, i.e. an absence of undesirable affect, despair, lonesomeness, anxiety, and sickness is not the same as the presence of positive affect, which refers to "happiness, social connection, trust, and wellness" (Butler \& Kern, 2016, p. 2). Considering the emotional and cultural realities the pandemic has exposed, teachers recognize how they cognitively represent and emotionally face parents who are fearful and uncertain of their children's future (Garbe et al., 2020). Lueng et al. (2020) advocated for providing a social safety net in disadvantaged communities, especially in which the assistance of social workers may be enlisted who can actively assist parents in dealing with family issues arising from the 
situation. Furthermore, communities may provide a supportive role in managing difficulties through parent committees, who work hand in hand with schools to address learners' needs, and to fulfil curriculum needs while maintaining their health (Lueng et al., 2020). It is evident that the impact of and exposure to negative emotions may be devastating for teachers. If teachers become more resilient to withstand any crisis, their well-being would ultimately be secured.

The implications for the current study is are in highlighting SEL competencies for teachers in rural schools. These competencies include self-awareness, social awareness and self-discovery.

\section{Self-awareness}

Practitioners and researchers regard self-awareness as a primary means of easing psychological distress and a necessary self-development pathway for psychologically strong individuals. Self-awareness may be extended beyond well-being and mental health to include factors that significantly impact on day-to-day functioning. To be self-aware, teachers should remain curious about the effects of a pandemic such as Covid-19 on them and their learners, amongst others (Esmailizadeh et al., 2019). In so doing, teachers they will be able to position themselves as independent and active learners while preparing themselves and their learners for real-life situations. A cCurious self-awareness will ultimately foster mindfulness and encourage persistence, while teachers become assertive in dealing with everyday stressors, but chiefly the ability to find the resilience within themselves when faced with major crises (Esmailizadeh et al., 2019) becomes all-important. Self-awareness may augment self-consciousness in that teachers acquire the skills of strengthening social participation, and shaping relationships with others (Park, 2015). Equally, they become transformative change representatives who apply emotionally stronger and more inclusive and reflective practices that will stand them in good stead to build a culture that is supportive of sustainable self-development (Hildesheim \& Sonntag, 2020).

\section{Social Awareness}

Social awareness may be considered as an individuals' capacity to appreciate the state of others in all aspects at an exact time. Factors such as their emotional state and environmental conditions come into play (Kim \& Liu, 2017). Teachers, in particular, should consider that learners are social beings and they should be acutely aware of the dominant norms of humankind, developing human beings to strive for stability, harmonizing social life, getting to know individuals' status and role, thereby imparting views or attitudes that empower them to overcome social problems (Newman \& Newman, 2014). To be socially aware, teachers should: understand their own cultural identity and its implications towards and impact on the lives of others (Gray, 2012), portray an affirming attitude toward colleagues, learners, and parents (García \& Guerra, 2004), and practice the belief that everyone is a citizen in a democracy (Huitt, \& Dawson, 2011). As socially aware individuals, teachers should continually inspect their own socio-cultural identities and biases in relation to ethnically and culturally diverse segments of society (Krasnoff, 2016). In so doing, they may enact transformation beyond the impact of Covid-19, as they may have learned tolerance and respect afresh, while practicing a variety of abilities such as critical thinking, intervention, negotiation, and partnership (Horner et al., 2015). 


\section{Self-discovery}

Generally, an individual has an innate, ontologically real, authentic self that he or she chooses to make known or use chiefly as standard practice to make decisions. As Schlegel et al. (2013, p. 217) stated, "The belief that the self is discovered is important to the perceived validity of the true self because it implies that an underlying true self exists and simply is waiting to be found." Kray et al. (2010) suggested that when an event befalls an individual, and he or she realizes the improbability thereof, it is often easier to assume and conclude that it was intended to be, which augments its particular meaning. The journey to self-discovery is often a road on which detecting, uncovering, finding, locating, or unearthing something about reality or oneself that already exists, is unpredictable. As Waterman (1984) explained,

To say that we have made a discovery means that we have come to recognize something about the nature of the world or ourselves. That which is found is something that already exists. Now it is recognized and understood. Discovery is the process of making the unknown, known. (p. 332)

Interventions to improve teachers' social-emotional competence and stress management in school have in the recent past, been based on mindfulness: Cultivating Awareness and Resilience in Education (CARE) and Stress Management and Resiliency Training (SMART). Their socio-cultural and emotional competence and wellbeing are reflected in their interactions with their learners and are crucial to ensuing instructional and emotional support in ways that provide safe and supportive learning environments. (Schonert-Reichl, 2017).

In the words of Yeager and Dweck (2012), we argue that a discovery of the self, presented by conditions such as the Covid-19 pandemic, implies that teachers may discover within themselves a socio-cultural consciousness. Hence, they make meaning of their value, enhance their decision-making roles, and regulate their own behaviour. A discovery of the self may further contribute to teachers transforming their classroom practices in that they deliberately work towards fostering success and promoting equitable and socially responsible practices to the benefit of the self, the school, and their community (Vaccaro \& Newman, 2016).

\section{Conclusion}

In the face of a global pandemic, it is difficult for teachers to avoid emotions such as stress, anxiety, depression, uncertainty, and hopelessness. The unequal education system in South Africa deepened the crisis teachers in rural schools found themselves. The COVID -19 pandemic has exposed the social emotional challenges faced by teachers around the world. By affording South African teachers an opportunity to make their voices heard, they (teachers) were positioned to echo their fears and anxieties about Covid-19, and they obtained reassurance that attention is paid to their needs for support. The strategies indicated in this paper imply that teachers may be positioned to strive toward inclusive teaching while developing their ability to manage their emotions, show empathy and establish and maintain positive relationships and make responsible decisions. Teachers around the world can use information in this study as an illustration as to how to improve their social emotional competences, teaching and learning process. A comparative study on teachers' social emotional development during times of crisis, like Covid-19, may be an interesting topic for research in the future. 


\section{Limitations}

This study had a number of limitations. Firstly, although Covid-19 constitutes a global humanitarian crisis and, while previous research points to high levels of learner stress and deficiency of coping strategies even in normal circumstances (Bewick et al., 2010; Deasy et al., 2014), the study presents teachers in five rural schools recounting their experiences during the pandemic. The findings may, therefore, not be generalized as it may not be representative of all teachers' experiences. Secondly, there are noticeable differences between the external and internal conditions of the schools represented by respondents participants in the study. Thirdly, the data gathered did not permit an in-depth investigation of the nature of the stressors and anxieties and fears the teachers experienced, and the level of coping skills applied in their situations.

\section{References}

Affouneh, S., Salha, S. N., \& Khlaif, Z. (2020). Designing quality e-learning environments for emergency remote teaching in coronavirus crisis. Interdisciplinary Journal of Virtual Learning in Medical Sciences, 11(2), 1-3.

Ames, H., Glenton, C., \& Lewin, S. (2019). Purposive sampling in a qualitative evidence synthesis: A worked example from a synthesis on parental perceptions of vaccination communication. BMC Medical Research Methodology, 19(1), 26-34. https://doi.org/ 10.1186/s 12874-019-0665-4

Aspers, P., \& Corte, U. (2019). What is qualitative in qualitative research. Qualitative Sociology, 42(2), 139-160. https://doi.org/10.1007/s11133-019-9413-7

Azevedo, J. P., Hasan, A., Goldemberg, D., Iqbal, S. A., \& Geven, K. M. (2020). Simulating the potential impacts of COVID-19 school closures on schooling and learning outcomes: A set of global estimates'. policy research (Working Paper No. 9284). World Bank.

Banks Henries, A. D. (1977). Black African cultural identity. Présence Africaine Editions, 1(2), 119-128. https://doi.org/10.3917/presa.101.0119

Bent-Goodley, T., Fairfax, C. N., \& Carlton-LaNey, I. (2017). The significance of Africancentered social work for social work practice. Journal of Human Behavior in the Social Environment, 27(1-2), 1-6. https://doi.org/10.1080/10911359.2016.1273682

Berry, T. R., Candis, M. R., \& Reese, M. (2013). Cultural identity and education: A Critical Race perspective. Education Foundations, 27(3-4), 43-64. https://files.eric.ed.gov/ fulltext/EJ1065655.pdf

Bewick, B., Koutsopoulou, G., Miles, J., Slaa, E., \& Barkham, M. (2010). Changes in undergraduate students' psychological well-being as they progress through university. Studies in Higher Education, 35(6), 633-645. https://doi.org/10.1080/03075070903216643

Blewitt, C., O'Connor, A., Morris, H., Mousa, A., Bergmeier, H., Nolan, A., Jackson, K., Barrett, H., \& Skouteris, H. (2020). Do curriculum-based social and emotional learning programs in early childhood education and care strengthen teacher outcomes? A systematic literature review. International Journal of Environmental Research \& Public Health, 17(3), 1049. https://doi.org/10.3390/ijerph17031049

Bongani, Z. (2020). Teachers' fears are real and they need a willing ear. New Frame. https://www.newframe.com/teachers-fears-are-real-and-they-need-a-willing-ear/

Burns, M., \& Lawrie, J. (Eds.). (2015). Where it's needed most: Quality professional development for all teachers. Inter-Agency Network for Education in Emergencies. 
https://www.researchgate.net/publication/270884050_WHERE_IT'S_NEEDED_MO ST

Butler, J., \& Kern, M. L. (2016). The PERMA-profiler: A brief and multidimensional measure of flourishing. International Journal of Wellbeing, 6(3), 1-48. https://doi.org/ 10.5502/ijw.v6i3.526

Caldarella, P., Millet, A. J., Heath, M. A., Warren, J. S., \& Williams, L. (2019). School counselors' use of social emotional learning in high school: A study of the strong teens curriculum. Journal of School Counseling, 17(19), 1-35. https://files.eric.ed.gov/ fulltext/EJ1219658.pdf

Čecho, R., Švihrová, V., Čecho, D., Novák, M., \& Hudečková, H. (2019). Exposure to mental load and psychosocial risks in kindergarten teachers. National Institute of Public Health, Slovenia, 58(3), 120-128. https://doi.org/10.2478/sjph-2019-0016

Collaborative for Academic, Social, and Emotional Learning. (2013). Effective Social and Emotional Learning Programs. Retrieved December 7, 2020, from http://www.casel.org/social-andemotional-learning/.

Collaborative for Academic, Social, and Emotional Learning. (2019). What is SEL? https://casel.org/what-is-sel/

Creswell, J. W. (2007). Qualitative inquiry and research design (2nd ed.). SAGE Publications.

Creswell, J. W. (2013). Qualitative inquiry and research design: Choosing among five approaches. Sage.

Cropley, A. J. (2019). Qualitative research methods: A practice-oriented introduction for students of psychology and education (2nd ed.). Zinātne

Darling-Hammond, L., Cook-Harvey, C., Flook, L., Gardner, M., \& Melnick, H. (2018). With the whole child in mind: Insights from the Comer School Development Program. ASCD.

Darling-Hammond, L., Flook, L., Cook-Harvey, C., Barron, B., \& Osher, D. (2020). Implications for educational practice of the science of learning and development. Applied Developmental Science, 24(2), 97-140. https://doi.org/10.1080/10888691.2018.1537791

Deasy, C., Coughlan, B. J., Pironom, D. J., Jourdan, D., \& Mannix-McNamara, P. (2014). Psychological distress and coping amongst higher education students: A mixed method inquiry. PloS One, 9(12), 115-193. https://doi.org/10.1371/journal.pone.0115193

Denzin, N. K., \& Lincoln, Y. S. (1998). Collecting and interpreting qualitative materials. Sage.

Dhawan, S. (2020). Online learning: A panacea in the time of COVID-19 crisis. Journal of Educational Technology Systems, 49(1), 5-22. https://doi.org/10.1177/ 0047239520934018

Duan, L., \& Zhu, G. (2020). Psychological interventions for people affected by the COVID-19 epidemic. The Lancet Psychiatry, 7(4), 300-302. https://doi.org/10.1016/S22150366(20)30073-0

Ebneyami, S., \& Moghadam, M. R. S. (2018). Toward developing a framework for conducting case study research. International Journal of Qualitative Methods, 17(1), 1-11. https://doi.org/10.1177/1609406918817954

Eddy, M., Blatt-Gross, C., Edgar, S. N., Gohr, A., Halverson, E., Humphreys, K., \& Smolin, L. (2020). Local-level implementation of Social Emotional Learning in arts education: Moving the heart through the arts. Arts Education Policy, 2020, 1-12. https://doi.org/10.1080/10632913.2020.1788681

Esmailizadeh, F., Tabatabaee Lotfi, S. A., \& Ashari Tabar, N. (2019). The effects of guideddiscovery, self-discovery, and situational-presentation techniques on learning conditional sentences in English. Applied Linguistics Research Journal, 3(3), 51-63. https://doi.org/10.14744/alrj.2019.27247 
Ewuoso, C., \& Hall, S. (2019). Core aspects of Ubuntu: A systematic review. South African Journal of Bioethics \& Law, 12(2), 93-103. https://doi.org/10.7196/SAJBL.2019.v12i2.679

Fataar, A. (2020). Teachers courageously confront challenge of teaching during COVID-19 pandemic. http://www.sun.ac.za/english/Lists/news/DispForm.aspx?ID=7452

Ferreira, M., Martinsone, B., \& Talic, S. (2020). Promoting sustainable social emotional learning at school through relationship-centered learning environment, teaching methods and formative assessment. Journal of Teacher Education for Sustainability, 22(1), 21-36.

Garbe, A., Ogurlu, U., Logan, N., \& Cook, P. (2020). Parents' Experiences with Remote Education during COVID-19 School Closures. American Journal of Qualitative Research, 4(3), 45-65. https://doi.org/10.29333/ajqr/8471

García, S. B., \& Guerra, P. L. (2014). Deconstructing deficit thinking. Working with educators to create more equitable learning environments. Education \& Urban Societies, 36(2), $150-168$.

Glazzard, J., \& Rose, A. (2019). The impact of teacher well-being and mental health on pupil progress in primary schools. Journal of Public Mental Health, (Vol. ahead-of-print) No. ahead-of-print. https://doi.org/10.1108/JPMH-02-2019-0023

Gray, S. (2012, August 22). 5 ways to create a culturally responsive classroom. National Equity Project. https://www.nationalequityproject.org/blog/5-ways-to-create-a-culturallyresponsive-classroom

Green, T. (2020). Social emotional learning during Covid-19. Magzter. https://www.magzter. com/article/News/TerraGreen/Social-Emotional-Learning-During-the-COVID-19Pandemic

Halpern, C. (2020). Distant Learning: The Experiences of Brazilian Schoolteachers during the COVID-19 School Closures. Journal of Ethnic and Cultural Studies, 8(1), 206-225.

Hapanyengwi-Chemhuru, O., \& Makuvaza, M. (2017) Re-thinking education in postcolonial Africa. Middle East Journal of Scientific Research, 12(7), 938-944.

Henard, F., \& Leprince-Rinquet, S. (2008). The path to quality teaching in higher education. OCED. http://www.oecd.org/education/imhe/41692318.pdf

Hildesheim, C., \& Sonntag, K. (2020). The quality culture inventory: A comprehensive approach towards measuring quality culture in higher education. Studies in Higher Education, 45, 892-908. https://doi.org/10.1080/03075079.2019.1672639

Horner, L., Kadiwal, L., Sayed, Y., Barrett, A., Durrani, N., \& Novelli, M. (2015). Literature review: The role of teachers in peace building. UNICE. http://learningforpeace.unicef.org/ wpcontent/uploads/2015/10/The-Role-of-Teachersin-Peacebuilding-Executive-Summary-Sept15

Huitt, W., \& Dawson, C. (2011). Social development: Why it is important and how to impact it. http://www.edpsycinteractive.org/papers/socdev.pdf

Idang, G. E. (2015). African culture and values. Phronimon, 16(2), 97-111.

Idoiaga, N., Berasategi, N., Eiguren, A., \& Picaza, M. (2020). Exploring children's social and emotional representations of the COVID-19 pandemic. Frontiers in Psychology, 11, 1952. https://doi.org/10.3389/fpsyg.2020.01952

Jagers, R. J., Rivas-Drake, D., \& Borowski, T. (2018). Equity and social-emotional learning: A cultural analysis. CASEL Assessment Work Group Brief series. https://measuringsel.casel.org/wp-content/uploads/2018/11/Frameworks-Equity.pdf

Jandrić, P., Hayes, D., Truelove, I. et al. (2020). Teaching in the age of Covid-19. Postdigital Science and Education. https://doi.org/10.1007/s42438-020-00169-6

Jansen, J. (2020, April 9). Let's face facts, the 2020 school year is lost. So what to do? Times Select. http://archive.is/UMaJq\#selection-353.0-353.62 
Katbi, H. A., \& Abdeen, L. F. (2016). Culture and imperialism in Chinua Achebe's 'Things Fall Apart'. World Applied Sciences Journal, 34(1), 89-93. https://doi.org/10.5829/idosi.wasj. 2016.34.1.22953

Kelley, D. (2020). The Person Within the Mask: Mask-Wearing, Identity, and Communication. American Journal of Qualitative Research, 4(3), 111-130. https://doi.org/10.29333/ajqr/8712

Kim, S., Raza, M., \& Seidman, E. (2019). Improving 21st-century teaching skills: The key to effective 21st century learners. Research in Comparative \& International Education, 14(1), 99-117. https://doi.org/10.1177/1745499919829214

Kim, T. Y., \& Liu, Z. (2017). Taking charge and employee outcomes: The moderating effect of emotional competence. The International Journal of Human Resource Management, 28(5), 775-793. https://doi.org/10.1080/09585192.2015.1109537.

Korstjensa, I., \& Moserb, A. (2018). Series: Practical guidance to qualitative research. Part 4: Trustworthiness and publishing. European Journal of General Practice, 24(1), 120-124. https://doi.org/10.1080/13814788.2017.1375092

Koutsimani, P., Montgomery, A., \& Georganta, K. (2019). The relationship between burnout, depression, and anxiety: A systematic review and meta-analysis. Frontiers in Psychology, 10, 1-19. https://doi.org/10.3389/fpsyg.2019.00284

Krasnoff, B. (2016). Culturally responsive teaching. A guide to evidence-based practices for teaching all students equitably. Equity Assistance Center of Education Northwest. https://educationnorthwest.org/sites/default/files/resources/culturally-responsiveteaching-508.pdf

Kray, L. J., George, L. G., Liljenquist, K. A., Galinsky, A. D., Tetlock, P. E., \& Roese, N. J. (2010). From what might have been to what must have been: Counterfactual thinking creates meaning. Journal of Personality \& Social Psychology, 98(1), 106-118. https://psycnet.apa.org/doi/10.1037/a0017905

Kundu, A. (2017). Grit and agency: A framework for helping students in poverty to achieve academic greatness. National Youth At-Risk Journal, 2(2), 69-80. https://digitalcommons.georgiasouthern.edu/cgi/viewcontent.cgi?article=1054\&contex $\mathrm{t}=$ nyar

Le Grange, L. (2020). COVID-19 Pandemic and the prospect of education in South Africa. Prospects, 2020, 1-12. https://doi.org/10.1007/s11125-120-09514-w

Leedy, P. D., \& Ormrod, J. E. (2005). Practical research: Planning and design (8th ed.). Prentice-Hall.

Lifelong Learning Platform. (2020). COVID-19: Mental health and well-being of all learners come first. http://lllplatform.eu/lll/wp-content/uploads/2020/04/LLLP-StatementCOVID-19. pdf

Liguori, E. W., \& Winkler, C. (2020). From offline to online: Challenges and opportunities for entrepreneurship education following the COVID-19 pandemic. Entrepreneurship Education \& Pedagogy, 3(4), 346-351. https://doi.org/10.1177\%2 F2515127420916738

Lueng, C. C., Lam., T. H., \& Cheng, K. K. (2020, March 2). Mass Masking in the COVID-19 epidemic: People need guidance. The Lancet, 395. [Published Online]. https://doi.org/10.1016/ S0140-6736(20)30520-1

MacIntyre, P. D., Gregersen T., \& Mercer, S. (2020). Language teachers' coping strategies during the Covid-19 conversion to online teaching: Correlations with stress, well-being and negative emotions. System, 94, 1-12. https://dx.doi.org/10.1016\%2Fj.system. 2020.102352

MacIntyre, P. D., Ross, J., Talbot, K., Mercer, S., Gregersen, T., \& Banga, C. A. (2019). Stressors, personality and well-being among language teachers. System, 82, 26-38. https://doi.org/10.1016/j.system.2020.102352 
Macupe, B. (2020, July 14). Another teachers' union calls for schools to be closed. Mail \& Guardian. https://mg.co.za/education/2020-07-14-another-teachers-union-calls-forschools-to-be-closed/

Madeline, W. (2020, April 8). Expectation for online student behavior vary during coronavirus school closures. Education Week. https://blogs.edweek.org/teachers/teaching_now/ 2020/04/during_virtual_classes_how_much_should_school_rules_be_enforced.html

Mahaye, N. E. (2020). The impact of COVID-19 pandemic on education: Navigating forward the pedagogy of blended learning. https://www.researchgate.net/publication/ 340899662_The_Impact_of_COVID-

19_Pandemic_on_South_African_Education_Navigating_Forward_the_Pedagogy_of_ Blended_Learning

McMillan, J. H., \& Schumacher, S. (2014). (Eds). Research in education: Evidence-based inquiry (7th ed.). Pearson.

Merriam, S. B. (1998). Qualitative research and case study applications in education (2nd ed.). Jossey-Bass Publishers.

Merriam, S. B. (2002). Qualitative research in practice: Examples for discussion and analysis. Jossey-Bass.

Namli, U. (2021). Behavioral Changes among Street Level Drug Trafficking Organizations and the Fluctuation in Drug Prices Before and During the Covid-19 Pandemic. American Journal of Qualitative Research, 5(1), 1-22. https://doi.org/10.29333/ajqr/9691

Namrata, V. (2020, April 8). Challenges faced by teachers and students during covid-19 lockdown. AMC. https://www.amcgroup.edu.in/blog/

Newman, B. M., \& Newman, P. R. (2014). Development through life (12th ed.). Cengage Learning.

Oswald, M., \& Perold, M. (2015). A teacher's identity trajectory within a context of change. South African Journal of Education, 35(1), 1-8. Retrieved October 7, 2020, from http://www.sajournalofeducation.co.za/index.php/saje/article/view/1046/500

Park, H. (2015, May 19-21). Learning identity a sociocultural perspective [Paper presentation]. 56th Annual Adult Education Research Conference, Manhattan, Kansas,. https://newprairiepress.org/aerc/ 2015/papers/41

Parker, R., Morris, K., \& Hofmeyr, J. (2020). Education, inequality and innovation in the time of COVID-19. JET Education Services.

Peirce, C. S. (1992). The fixation of belief. In N. Houser \& C. Kloesel (Eds.), The essential Peirce: Volume 1. Selected philosophical writings (1867-1893) (pp. 109-123). Indiana University Press.

Ramrathan, L. (2020). School curriculum in South Africa in the Covid-19 context: An opportunity for education for relevance. Prospects, 2020, 1-10. https://doi.org/10.1007/s11125-020-09490-1

Rapanta, C., Botturi, L., Goodyear, P., Guardia, L., \& Koole, M. (2020). Online university teaching and after the Covid-19 crisis. Refocusing teacher presence and learning activity. Postdigital Science \& Education, 2, 923-945. https://doi.org/10.1007/ s42438020-00155-y.

Ratislavová, K., \& Ratislav, R. (2014). Asynchronous e-mail interview as a qualitative research method in the humanities. Human Affairs, 24, 452-460. https://doi.org/10.2478/s13374014-0240-y

Republic of South Africa. (2020). Disaster management act: Amendment of regulations: Coronavirus COVID-19 lockdown. Pretoria Government Printer. Retrieved October 6, 2020, from https://www.gov.za/sites/default/files/gcis_document/202004/43232rg 11089gon465-translations_0.pdf 
Saxena, K. (2020). Coronavirus accelerates pace of digital education in India. EDII Institutional Repository. Retrieved October 6, 2020, from http://library.ediindia.ac.in:8181/xmlui// handle/123456789/10145

Schlegel, R. J., Hirsch, K. A., \& Smith, C. M. (2013). The importance of who you really are: The role of the true self in eudaimonia. In A. S. Waterman (Ed.), The best within us: Positive psychology perspectives on eudaimonia (pp. 207-225). American Psychological Association.

Schonert-Reichl, K. A. (2017). Social and emotional learning and teachers. The Future of Children, 27(1), 137-155. http://www.jstor.org/stable/44219025

Sherlaw, W., \& Raude, J. (2013). Why the French did not choose to panic: a dynamic analysis of the public response to the influenza pandemic. Sociology of Health Illness, 35, 332344. https://doi.org/10.1111/j.1467-9566.2012.01525.x

Smith, N., \& Joffe, H. (2013). How the public engages with global warming: A social representations approach. Public Understanding of Science, 22(1), 16-32. https://doi.org/10.1177/0963662512440913

Srivastava, G. (2020). Importance of social emotional learning during the COVID-19 pandemic. Retrieved December 7, 2020, from https://blogs.ibo.org/blog/2020/07/17/importance-of-social-emotional-learning-duringcovid-19-pandemic/

Stephen, T. T. T., Tim, B., \& Diep, N. (2019). Psycho-social work environment, work engagement, and employee commitment: A moderated, mediation model. International Journal of Hospitality Management, 88 [Article 102415]. https://doi.org/10.1016/j.ijhm. 2019.102415

Thakur, V., \& Jain, A. (2020). COVID 2019-suicides: A global psychological pandemic. Brain, Behavior, and Immunity, 88, 952-953. https://dx.doi.org/10.1016\%2Fj.bbi.2020.04.062

UNESCO. (2020). Policy brief: Education during COVID-19 and beyond. https://reliefweb.int/report/world/policy-brief-education-during-covid-19-and-beyondaugust-2020

Vaccaro, A., \& Newman, B. M. (2016). Development of a sense of belonging for privileged and minoritized students: An emergent model. Journal of College Student Development, 57(8), 925-942. https://doi.org/10.1353/csd.2016.0091

Van der Berg, S., \& Spaull, N. (2020). Counting the Cost: COVID-19 school closures in South Africa \& its impacts on children. Research on Socioeconomic Policy (RESEP). Stellenbosch University. Retrieved October 7, 2020, from http://resep.sun.ac.za/wpcontent/uploads/2020/06/Van-der-Berg-Spaull-2020-Counting-the-Cost-COVID-19Children-and-Schooling-15-June-2020-1.pdf

Veena, S., Sheetal, M., \& Navita, V. (2020). COVID 19 lockdown technology adaption, teaching, learning, students engagement and faculty experience. MuktShabd Journal, 9(4), 698-702.

Waterman, A. S. (1984). Identity formation: Discovery or creation? The Journal of Early Adolescence, 4(4), 329-341. https://doi.org/10.1177\%2F0272431684044004

Weisberg, R. O. (2020). Promoting the social and emotional learning of millions of school children. Perspectives on Psychological Science, 14(1), 65-69. https://doi.org/10.1177/1745691618817756

Wolf, S., Raza, M., Kim, S., Aber, J. L., Behrman, J., \& Seidman, E. (2018). Measuring and predicting process quality in Ghanaian pre-primary classrooms using the Teacher Instructional Practices and Processes System (TIPPS). Early Childhood Research Quarterly, 45, 18-30. https://doi.org/10.1016/j.ecresq.2018.05.003

Yamagata-Lynch, L. C., Skutnik, A. L., Garty, E., \& Do, J. (2016). Interactionist qualitative research as a semiotic mediation activity. SAGE Open, 6(3), 1-14. https://doi.org/10.1177\%2F2158244016666889 
Yeager, D. S., \& Dweck, C. S. (2012). Mindsets that promote resilience: When students believe that personal characteristics can be developed. Educational Psychologist, 47(4), 302314. http://dx.doi.org/10.1080/00461520.2012.722805

Yin, R. K. (2011). Applications of case study research. Sage.

Yin, R. K. (2017). Case study research and applications: Design and methods. Sage.

\section{Notes on Contributors}

Dr. June Monica Palmer is Senior Lecturer (Education Management and Leadership) in the Department of Postgraduate Studies at the Central University of Technology, Free State, South Africa. Her research interests include emotional intelligence, transformative school leadership, transformative learning, policy studies, teacher autonomy, pre-service teachers' development and inclusive learning pedagogies.

Dr. Edwin Darrell de Klerk is Senior Lecturer (Philosophy in Education) of the School of Education at Sol Plaatje University, South Africa. His research interests predominately focus on autonomy, pre-service teachers' development, teacher professional development, transformative learning, transformative school leadership, philosophy in education, policy studies and transformative social justice issues. Foucauldian studies is also an area of interest. Email:

Dr. Motalenyane Alfred Modise is a Senior Lecturer at Central University of Technology (CUT) in Free State Province, former Departmental Manager and currently Acting Assistant Dean at CUT, Free State Province. His research interests include accounting, transformation and change, pre-service teachers' development, pedagogical content knowledge, HIV/AIDS and education in rural areas. 